\title{
Resources on the Web
}

J ennifer Joyce Kesse, missing since 2006 when she failed to appear at work; Ethan Patz, missing since 1979 when he walked two blocks to school by himself; Natalie Holloway, missing since a 2005 high school trip to Aruba; Jacob Wetterling, missing since 1989 when he was biking home with his brother and a friend from a convenience store; and Morgan Nick, missing since 1995 from a Little League baseball game she was at with her mother. Some of the names may sound familiar, others you have never heard of. They are five of the 85,820 active missing person cases as of December 31, 2010, according to the National Crime Information Center (NCIC). ${ }^{1}$

This article provides information on resources concerning missing children and missing adults. Information is also provided on how to keep children safe and what steps to take if a person is missing.

\section{Resources on missing children and adults}

- America's Most Wanted (AMW). This site provides information on missing children and adults. Access is gained through links on the homepage. Both the Missing Children and Missing Persons page provide a Top Story on a missing person. Latest updates are provided on missing child and adult cases. The Missing Child page provides a link to current Amber Alerts and includes the history behind the alerts system. AMW cases on missing children and adults can be searched by age, race, sex, region, location, and missing date. One can also search for a case by name (brings up an alphabetical listing) or geographically in the United States by using an interactive map. Missing Child Resources provide access on what to do if your child is missing, information about international abductions, and learning how to keep your child safe. Access: http://www.amw.com.

- Let's Bring Them Home (LBTH). LBTH is a national program for missing adults. One of the goals of LBTH is to provide coordination between various agencies, the media, and families of missing adults. Another goal is to provide education on safety for adults and children. This organization also serves as a national repository of information available to the general public and law enforcement to aid in locating missing adults who are endangered. Profiles of the missing are viewable and users can search databases and view a map of missing adults in the United States and Canada. Access: http://www.lbth. org/ncma/content.php?webid=about_ncma.

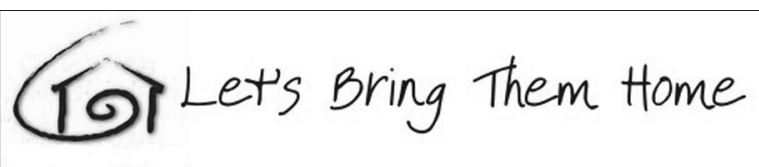

- Natalie Holloway Resource Center (NHRC). The National Museum of Crime and Punishment houses the Natalie Holloway Resource Center. NHRC focuses on education and the prevention of crime. Safety tips for traveling are provided under the Top Tips for Safer Travel. Checklists are available for

Karen Evans is librarian for criminology and criminal justice at Indiana State University, e-mail:karen.evans@ indstate.edu

(C) 2011 Karen Evans 
domestic and international travel. NHRC works with families of the missing, providing an action plan, poster templates, contacts, resources, and press releases. Access: http:// www.crimemuseum.org/NHRC/.

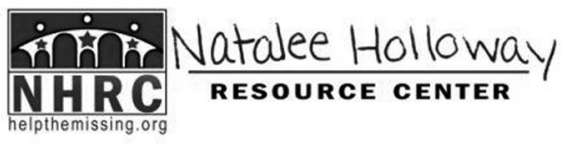

- United States Department of Justice: NamUS: National Missing and Unidentified Persons System. NamUS is a system that can be searched to solve missing and unidentified person cases. The system can be used by experts (coroners, law enforcement, etc.) or the public to locate information. The Missing Persons Database contains information about missing persons; anyone can enter the information. Information is verified before obtaining case status and entries are crosschecked for matches. NamUS can map out likely travel routes to search for a missing person. The resource provides links to state clearinghouses, medical examiners, law enforcement agencies, victim assistance groups, and legislation. Access: http://namus.gov/.

- United States Department of Justice: Report and Identify Missing Persons. This site provides links to numerous sites dealing with the abduction of children and adults. Information is provided on domestic and international parental kidnappings, including a FAQ section. A link to the Violent Criminal Apprehension Program profiles missing persons who may be victims of foul play. Access: http://www.justice.gov/actioncenter /missing-person.html.

\section{Resources on missing children}

- Federal Resources on Missing and Exploited Children. A 103-page work by the Federal Agency Task Force for Missing and Exploited Children. The taskforce was created by Attorney General Janet Reno in 1995 to coordinate resources and services in the effort to help missing, abducted, and exploited children. The directory provides information on the resources and assistance available during an investigation. Descriptions of each taskforce agency and its role in working to recover missing children are described. Access: http://www.ncjrs.gov /pdffiles1/ojjdp/206555.pdf.

- Hague Child Abduction. The Hague Convention on the Civil Aspects of International Child Abduction is a multilateral treaty. Its goal is to protect children from abduction across international boundaries by creating a process for returning children. An explanatory report on the 1980 document is available, as are several reports on various aspects of international child abduction, including judicial seminars on the international protection of children and "The Judges' Newsletter on International Child Protection." Access: http://www.hcch.net/index_en.php?act=text. display\&tid $=21$.

- International Child Abduction Remedies Act (ICARA). The public law, from the 100th Congress, establishes procedures for the implementation of the Hague Child Abduction. Definitions and judicial remedies are listed. The authority of the United States to handle cases is defined. Access: http:// www.travel.state.gov/pdf/International_Child _Abduction_Remedies_Act.pdf.

- International Resources on Missing Children A Report to the Attorney General on International Parental Kidnapping. Information on current federal practices dealing with international parental kidnapping including recovering the kidnapped child and facilitating a child's return to the United States. Another section concentrates on improving the U.S. federal response to international kidnapping by several means, including developing a more informed and coordinated response to kidnapping, developing a statistical database, improve implementation of the Hague Convention, and expanding diplomatic efforts to resolve kidnapping situations. Access: http://www. ncjrs.gov/pdffiles1/ojjdp/189382.pdf.

- Interpol: Missing Children. The site allows one to search for a missing child by physical characteristics, name, or age. An alphabetical search can also be performed. 
Interpol also provides the legislation of Interpol member countries on missing children. The site cautions that only a small fraction of the children missing worldwide are entered into the Interpol database. Access: http:// www.interpol.int/Public/Children/Missing /Default.asp.

\section{- Kentucky State Police: Missing Chil-} dren. The Kentucky Missing and Exploited Children unit was organized in 1984 to assist agencies in locating missing children. The Web site provides information on teaching your children important personal data, including their name, age, address, and a family password for safety issues. Tips for Parent provide advice on actions parents can take to ensure their child's safety. Tips include having up-to-date information on your child, including pictures and dental records. Additional information includes "Look for Warning Signs and Reporting a Missing Child." Access: http://www.kentuckystatepolice.ky.gov/ missing.htm.

- Missing Children Society of Canada. Created in 1986, the society has several programs and services geared toward missing children and their families. An Investigation Unit searches for missing children, while the Parent Support Program provides emotional and peer support. The society also conducts education and awareness programs to inform. Access: http://www.mcsc.ca/.
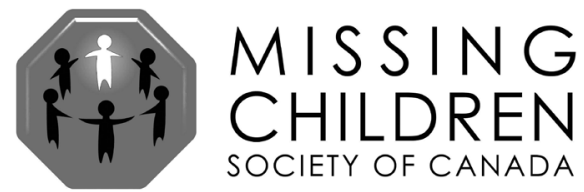

- Ohio Attorney General: Missing Persons Checklist. A checklist of various steps to take if a person is missing. Information is provided on contacting your local law enforcement organization to report a missing person. Six steps are listed to ensure you provide the most accurate and up-to-date information to law enforcement. The checklist also have also contains ten steps for family members and friends to follow that help investigators after a missing person's report is filed. Several steps are also listed on how to raise awareness in your community about the missing person. The last section provides tips on taking care of yourself while involved in a search for a missing person. Access: http:// www.ohioattorneygeneral.gov/Enforcement /Unsolved-Cases/Missing-Persons/Menu /Missing-Person-Resources/Missing-persons -checklist.

- Polly Klass Foundation. This nonprofit foundation was created after the abduction and murder of 12-year-old Polly Klass

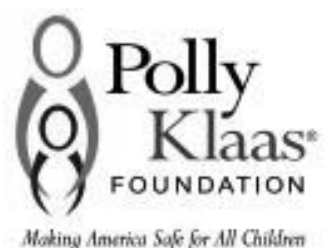
from her bedroom in 1993. The foundation has helped more than 7,500 families with missing children. Numerous services are provided by the foundation, including programs to educate children, parents, and others on ways to protect children; advocating, passing, and implementing public policies to protect children; a worldwide distribution of free abduction prevention materials on the Web site; a 24-hour hotline; and a response team of eVolunteers, who distribute posters of missing children in their communities. Access: http://www.pollyklaas.org.

- Resources for Parents and Family Members Federal Bureau of Investigation: Resources for Parents. Information on how the FBI investigates child abductions, including the CARD teams. The site also provides information on AMBER Alerts, missing children, and obtaining an ID kit for children. There's a link to the FBI Crimes Against Children site, which provides information on family and non-family child abductions. Federal statutes provides a link to federal laws concerning missing and abused children, including kidnapping and international parental kidnapping. Access: http://www.fbi. gov/stats-services/parents/.

- The National Center for Missing and Exploited Children (NCMEC). NCMEC is a private, nonprofit organization, created in 1984 by the passage of the Missing Children's Assistance Act by Congress. In the same year, 
President Ronald Reagan opened the National Center for Missing and Exploited Children, with its national 24-hour toll-free hotline for missing children. NCMEC serves as the nation's resource for missing children. Information and resources are available to law enforcement, parents, children and child victims, and others. Three sections, Help Now, Resources For, and Topics of Focus assist the user in locating needed information. Help Now provides information on Reporting a Sighting, CyberTipline, AMBER Alert, and Staying Informed. Resources For has items for Parents and Guardians, Law Enforcement, Childcare Providers, Attorneys, and the Media. Topics of Focus offer resources on If Your Child is Missing, Child Safety, Success Stories, and Natural Disasters. Access: http://www.missingkids.com.

- United States Department of Justice: The Crime of Family Abduction. Family abduction is one of the most common reasons for a child being abducted. Several issues are covered in this publication: what happens to a child who is abducted, what the parents are feeling while the child is missing, and how to deal with the aftershocks when a child is returned to his or her family. An extensive list of resources is available for the user. Former abducted children and former searching parents provide personal information on their experiences. Access: http://www.ncjrs.gov /pdffiles1/ojjdp/229933.pdf.

- United States Department of Justice: What About Me? Coping with the Abduction of a Brother or Sister. A resource for anyone who knows someone who was abducted. From siblings to friends, this resource provides suggestions on how to cope, from keeping a diary to asking question of your parents to feeling guilty because you because you fought with a sibling before they were abducted. Access: http://www.ncjrs.gov /pdffiles1/ojjdp/217714.pdf.

\section{- United States Department of Justice:} When Your Child is Missing: A Family Survival Guide. Parents of missing and murdered children assisted in creating this volume for families. The 114 pages cover various topics, including The Search, Law Enforce- ment, The Media, Volunteers, Rewards, and Family Considerations. It provides "firsthand knowledge and sound advice" about the steps to take when a child is missing. Access: http:// www.ncjrs.gov/pdffiles1/ojjdp/228735.pdf.

- United States Department of Justice: You're Not Alone: The Journey from Abduction to Empowerment. Young adults, who were abducted and have returned home, assisted in creating this volume. Five sections including Your Journey, Getting in the Driver's Seat, and Navigating the Roadblocks can provide help for those struggling with a return to their life after an abduction. Personal stories from those abducted provide an intimate view of recovery. Most of all, this resource provides hope to those working to recover from an abduction. Access: http:// www.ncjrs.gov/pdffiles1/ojjdp/221965.pdf.

- USA.gov: Missing Children. Provides AMBER Alerts by state, including contact information and a link to state AMBER plans, information on Code Adam and the Code Adam Alerts in government buildings, and the National Sex Offender Registry: National Search. Access: http://www.usa.gov/Citizen /Topics/Missing_Children.shtml.

\section{Note}

1. FBI's NCIC Web site, www.fbi.gov/about -us/cjis/ncic/ncic-missing-person-and -unidentified-person-statistics-for-2010. n

("Come together," cont. from page 329)

these additional studies and eventually to a set of standards we can all agree on.

\section{Notes}

1. Rachael Hu and Alison Meier, CDL Mobile Strategy Report, www.cdlib.org /services/uxdesign/docs/CDL_Mobile _Device_User_Research_final.pdf.

2. Dan Suchy (UC San Diego) and Alison Meier (CDL), Environmental Scan of Libraries' Mobile Sites Offerings, July 1, 2010.

3. "Best Practices for UC Library Home Pages Report" can be found at www. cdlib.org/services/info_services/instruct /UCLibraryHomePagesTF_Report.doc. $\boldsymbol{n}$ 